\title{
IMPACT OF DIGITAL TRANSFORMATION ON ACCOUNTING INFORMATION SYSTEMS - EVIDENCE FROM ALGERIAN FIRMS
}

\author{
Oualid MERAGHNI ${ }^{1}$, Latifa BEKKOUCHE ${ }^{2}$, Zakaria DEMDOUM ${ }^{3}$ \\ 1,2,3 University of Echahid Hamma Lakhdar, ElOued, Algeria \\ Corresponding author's e-mail: oualid_meraghni@yahoo.fr
}

\begin{abstract}
The study aims to demonstrate the conceptual and practical framework of digital transformation and its impact on accounting information systems by focusing on the requirements of digital transformation, such as the digital strategy, the necessary knowledge of the human element, and the effects and obstacles facing the digitization of accounting information systems. The study attempts to answer the following question: What is the impact of digital transformation on accounting information systems in business organisations? The study uses deductive reasoning, based on many previous studies, by applying it to a sample of 237 individuals active in about 120 firms operating in the Algerian environment through a questionnaire distributed in 2021. The study has found a weak degree of awareness of the importance of digital transformation, and a low effort to develop accounting information systems in line with the requirements of digital transformation, all due to the presence of several high-impact challenges.
\end{abstract}

Keywords: Accounting Information Systems; Digital Transformation.

JEL Classification: M15, M41

\section{INTRODUCTION}

The business environment has seen rapid developments as a result of the increasing degree of complexity, markets openness, and competition intensification, necessitating modern firms to pay close attention to the various data that emerge from the external and internal environment and to capitalize on the benefits offered by modern technologies in collecting various data, allowing them to identify strengths, seize opportunities, address weaknesses, and avoid threats.

Digital transformation refers to a completely new formation of organisations that adopt changes that can occur in all areas of the organisation, not only through technology but through the power of technology (Hess et al., 2016), as digital transformation requires rapid change and renewal processes in all aspects of the organisation, including its different organisational levels and functions. This includes the accounting job, so members of the accounting profession should not be indifferent to this transformation, but rather strive to develop themselves, transform themselves and move to the future.

This transformation is considered a necessity for the accounting profession to constantly renew and improve itself in parallel with developments in the digital age 
(Tekbas \& Nonwoven, 2018). In addition, the emergence of digital systems and faster and safer operations carried out by accountants in these systems make it necessary to change the social image of the profession. In the process of digitization, the transformation of the accounting profession by redesigning it will keep the profession up-to-date to meet the challenges of the digital age (Bygren, 2016). Therefore, accounting practitioners must continue their work by feeling responsible for thinking, designing, and creating to shape the future of the profession.

$\checkmark$ The main problem: Accounting information systems, including their components, are an essential source for converting data into information. Therefore, it is considered of great importance to all actors in the organisation, and in particular to decision-makers. That is what makes it necessary for them to be flexible and able to provide information with acceptable qualitative characteristics.

Accordingly, accounting information systems must be able to keep pace with digital changes and benefit from them. Thus, the following main research question can be formulated:

\section{What is the impact of digital transformation on accounting information systems in business organisations?}

$\checkmark$ Sub-questions: To answer the main question of our study, we put the following sub-questions:

- How important is digital transformation in business organisations?

- To what extent does digital transformation affect accounting information systems in business organisations?

- To what extent do business organisations face challenges related to digital transformation within accounting information systems in business organisations?

$\checkmark$ Hypotheses: To address the research questions, we propose the following provisional hypotheses:

- Decision-makers in business organisations consider the digital transformation of great importance;

- Business organisations are constantly working to develop their accounting information systems in line with the requirements of digital transformation;

- There is a high degree of challenges related to digital transformation within the accounting information systems.

$\checkmark$ Objectives of the study:

- To identify the conceptual framework of digital transformation and highlight its significance, benefits, risks, and challenges;

- To identify the extent to which economic institutions are aware of the importance of adopting digital transformation and its technologies in light of traditional information systems;

- To provide some predictions and indicators through which specialists in all sectors can be helped to identify the digital transformation and its 
manifestations and the extent of its impact on accounting information systems;

- To attract the attention of economic and public institutions to digital transformation and digitization of their information systems.

$\checkmark$ Study methodology: To address the main research objectives, the research uses quantitative methods, such as deductive reasoning, based on secondary data represented in previous articles related to the topic of digital transformation and accounting information systems. The study uses primary data through the study tool, which is a questionnaire for a sample of economic institutions within the Algerian environment in 2021, and analyses the data through statistical programs.

$\checkmark$ The research gap: This study is distinguished by the fact that it deals with the issue of digital transformation and its impact on accounting information systems in the Algerian environment, which differs from previous studies. The study also presents the advantages and obstacles of digital transformation in Algeria.

\section{LITERATURE REVIEW}

Many researchers have addressed the issue of the relationship between digital transformation and accounting information systems from different perspectives, with different research tools, and within a distinct study community.

Nguyen et al. (2021) concluded that digital transformation processes will allow managers to take advantage of the effort related to accounting work and the attendant errors to search for customers and focus on improving product quality and increasing the organisation's competitiveness.

In the study of Othman and AL-Dweikat (2021), it has been found that there is a tangible impact of managing the risks of digital transformation in making appropriate information that serves the makers and users of accounting data.

The study of Thipwiwatpotjana (2021) concludes that the determinants of digital transformation ability are executive leaders, business model, organisational structure, the possibility of access to external resources, and support.

In addition, the study by Phornlaphatrachakorn and NaKalasindhu (2021) shows that digital accounting is of great importance in influencing accounting information and the quality of financial reports, thus increasing the effectiveness of strategic decisions.

The study of Saed (2020) concludes that there are two important dimensions to the subject, namely, accounting maturity and the need and readiness for digital transformation.

The study of Timchev (2020) sheds light on the analysis of the accounting business of companies within the conditions of competition and digital transformation, which includes the strategic and operational levels.

The study of Parlak (2020) shows that digital transformation has a tangible impact on accounting information systems and the accounting profession, from memorising, classifying, and summarising to analysing and discussing financial statements, establishing the system, and ensuring the effective continuity of the system. It is, therefore, necessary for members of the accounting profession to use the developed systems to adapt to this transformation process effectively. 
The study by Lazarova (2019) concludes that the formation of digital transformation is not only within higher administrative levels, but includes all levels and functions of institutions, including accounting and finance.

The study of Oncioiu et al. (2019) allows identifying digital transformation within management accounting systems, and the topic is addressed by presenting theoretical concepts on the subject. In general, this paper presents how electronic accounting has developed within enterprises, in addition to understanding digital transformation processes through the exchange of knowledge and the respective effects on the leaders who supervise management accounting.

The study by Begum (2019) was based on the deductive approach. The questionnaire, used as a tool for the study, was distributed to a sample of 40 respondents. The questionnaire included various digital technologies in accounting, and the weakness of the digital capabilities of institutions was assessed.

Rehm (2017) highlighted how to prepare accounting information systems for digital transformation, and the topic was addressed by presenting the most important steps to be followed through a general description of the administrative documentation process, preparing a guide for the process of accounting documents, defining principles and directions measures to be taken in exceptional cases, documentation of operating procedures.

Finally, Demiröz and Heupel (2017) have found that there is a lack of awareness among business organisations of the overall benefits of digital transformation, as many of these organisations are still in the first steps of digital transformation due to internal obstacles.

Table 1. Previous Studies

\begin{tabular}{|l|l|}
\hline \multicolumn{1}{|c|}{ The study } & \multicolumn{1}{|c|}{ Variables and concepts focused on } \\
\hline Nguyen et al., 2021 & $\begin{array}{l}\text { Developing a digital strategy, digitizing documents, and accounting } \\
\text { processes. }\end{array}$ \\
\hline $\begin{array}{l}\text { Othman \& AL-Dweikat, } \\
2021\end{array}$ & $\begin{array}{l}\text { Digital transformation risks, the outputs of the accounting } \\
\text { information system. }\end{array}$ \\
\hline Thipwiwatpotjana, 2021 & $\begin{array}{l}\text { Digital transformation capability (executive leadership, business } \\
\text { model, organisational structure, ability to access resources and } \\
\text { external support). }\end{array}$ \\
\hline $\begin{array}{l}\text { Phornlaphatrachakorn \& } \\
\text { Na Kalasindhu, 2021 }\end{array}$ & The quality of financial reports in light of digital accounting. \\
\hline Saed, 2020 & Accounting maturity, needs, and readiness for digital transformation. \\
\hline Timchev, 2020 & $\begin{array}{l}\text { Evaluating the digital transformation in the accounting business } \\
\text { through the balanced scorecard. }\end{array}$ \\
\hline Parlak, 2020 & $\begin{array}{l}\text { Qualifying the human element (accountants) to adapt to the digital } \\
\text { transformation. }\end{array}$ \\
\hline Lazarova, 2019 & $\begin{array}{l}\text { Focusing on all organisational levels, including the functional aspect } \\
\text { (accounting and finance functions) of digital transformation. }\end{array}$ \\
\hline Oncioiu \& al., 2019 & $\begin{array}{l}\text { Focusing on the knowledge side of accountants to adapt to the digital } \\
\text { transformation. }\end{array}$ \\
\hline Begum, 2019 & \begin{tabular}{l} 
Obstacles to digital transformation in economic institutions. \\
\hline
\end{tabular} \\
\hline
\end{tabular}




\begin{tabular}{|l|l|}
\hline Rehm, 2017 & $\begin{array}{l}\text { Digital transformation steps (description of the movement of } \\
\text { administrative documents, description of the movement of } \\
\text { accounting documents, description of exceptional procedures, and } \\
\text { documentation of operating procedures). }\end{array}$ \\
\hline $\begin{array}{l}\text { Demiröz \& Heupel, } \\
2017\end{array}$ & The advantages of digital transformation in accounting. \\
\hline $\begin{array}{l}\text { Our study: focuses on } \\
\text { 1- Awareness of the importance of digital transformation, paying attention to digital strategy, } \\
\text { i.e., the strategy covers all organisational levels, attention to cyber security when implementing } \\
\text { the strategy; } \\
\text { 2- Digital transformation practices within accounting information systems, i.e., examining the } \\
\text { knowledge aspect of the staff, evaluation, and development of the accounting information } \\
\text { system, analysis of obstacles; } \\
\text { 3- Challenges of digital transformation within accounting information systems, i.e., considering } \\
\text { controlling digital technologies, legal framing, adequate knowledge of accounting, quality of } \\
\text { accounting information, cost and return. }\end{array}$ \\
\hline
\end{tabular}

Note: Developed by the researchers based on previous literature.

\section{CONCEPTUAL FRAMEWORK}

Today, a lot of firms are investing in thought and behaviour change to bring about a traditional transformation in the way work is done by taking advantage of the great technological development that is taking place to serve the beneficiaries faster and better, as digital transformation provides huge potential to build effective and competitive sustainable societies, by making a deep change in the services of various parties (e.g., consumers, employees, beneficiaries), while improving their experiences and productivity through a series of proportional processes, accompanied by reformulating the necessary procedures for activation and implementation. Digital transformation requires enabling a culture of creativity in the work environment, and includes changing the basic components of work, starting with infrastructure, business models, and ending with digital marketing of services and products.

\subsection{Definition of Digital Transformation}

Digital transformation is defined as the process of companies moving to business models based on digital technologies and developments accompanying the Fourth Industrial Revolution (Vial, 2019) through the use of artificial intelligence, big data analytics, cloud computing, and the internet of things to support the development and innovation of products and services (Akter et al., 2020), and provide new marketing capabilities and job opportunities that increase the value of their products (Phornlaphatrachakorn \& Na Kalasindhu, 2021).

\subsection{Digital Transformation Steps}

Digital transformation begins by formulating a digital strategy and making an improvement to the current situation of the organisation (Saarikko et al., 2020). This can only be achieved by measuring the current digital capabilities and 
determining the best work structure for digital marketing activities in the organisation. After that, the requirements for investment plans are identified with the identification of digital integration obstacles to working a comprehensive and tight plan for all circumstances, and to push the transformation into the desired situation (Baethge-Kinsky, 2020), and finally, the necessity of having change management for digital transformation to achieve the strategic goals (Correani et al., 2020).

In this context, we find that AWS- a leading company in the field of cloud computing - has provided a checklist to build strategies that allow freedom to innovate and develop ways of working to achieve the successful digital transformation that is based on transforming vision, adopting a culture of change, changing the cost model, starting businesses in the cloud, and following the application process (Nguyen et al., 2021).

\subsection{Aspects of Digital Transformation Affecting Accounting Information Systems}

The great digital revolution in the Internet and communications networks led to a wide and rapid change in the business environment, which made it imperative for organisations to keep pace with these huge developments to move accounting and management information systems from classic methods to modern digital methods (Andreassen, 2020). We do not mean here information systems that depend on computers and various applications, and traditional accounting programs, which have outlived time globally after the emergence of digital entities, which have revolutionized the pattern of business conduct by setting standards that allow each facility to choose technologies commensurate with the nature of its work such as artificial intelligence, Internet of Things, Blockchain technologies, Big Data, Cloud Computing, and Cyber Security (Begum, 2019). These technologies will allow increasing transparency and reducing cost, saving effort and time, facilitating data access, protecting data and enhancing efficiency in the work of the accounting information system (Oncioiu et al., 2019).

Blockchain: It is an information network that contains a group of devices or nodes, each of which represents a database and a ledger, where all transactions that take place within the network are subject to verification and confirmation of their validity by the rest of the network devices (Akter et al., 2020). This technology helps in developing accounting information systems by giving transparency and moving from double entry to more automatic triple entry in record keeping. Accounting reduces the margin of error in preparing financial reports and shortens the time and effort expended by accountants, as the accounting recording of transactions will be directly in a common ledger among all dealers in the chain, thus creating more intertwined accounting systems (Faccia, 2019).

Cloud Computing: It is not just a technical solution or a server that has been stored and has another impact, but rather a form of digital transformation that improves the implementation of accounting work (Demiröz \& Heupel, 2017). The most important advantages of cloud computing are saving effort and time and thus reducing cost, speed in processing and data storage, scalability, data protection, 
easy data connectivity, ensuring services are always running, and benefiting from the huge infrastructure provided by cloud services (Al-Zoubi, 2017).

Big Data: It represents a huge amount of complex data that exceeds the capacity of traditional software and computer mechanisms to store, process, and distribute them (Yao \& Gao, 2020). Big data can be used in accounting as it enables companies to benefit from the analysis of data generated by financial markets and social media to identify their audience and predict the results of marketing and sales campaigns.

\subsection{Challenges Facing Digital Transformation}

Many factors prevent the process of digital transformation within organisations, including the lack of the human resource (Mitrofanova et al., 2018), the lack of budgets allocated to these programs limiting their growth (Gupta, 2018). Fear of information security risks, as a result of the use of technological means, is one of the biggest obstacles, especially if the assets are of high value (Rehm, 2018), and the absence of a regulatory legal framework especially in developing countries.

\section{METHODS AND TOOLS}

Given the importance of the field aspect, through which theoretical knowledge is applied to the study sample, the section presents all the means used in the data, as well as the statistical methods used to process the data in order to reach a perception about the study community and prove or deny the hypotheses.

\subsection{Data Collection Tool}

To collect data, the questionnaire was used as a tool for data collection. Questions were prepared according to the Rensis Likert five-point scale to determine the opinions of the sample members. The questionnaire came through a set of 24 questions (4 questions about the personal and functional characteristics, 7 questions about the first axis, 7 questions about the second axis, and 6 questions about the third axis).

\subsection{Study Population and Sample}

Study population: The study included a group of managers, accountants, and heads at some economic institutions active in the Algerian environment.

$\checkmark$ Study sample: The questionnaire was distributed to a simple random sample consisting of about 120 institutions that varied between the sectors of communications, insurance, food industries, cleaning materials industries, etc., where one to three questionnaires were distributed to each institution according to their size, number of administrative staff related to strategic decisions, as well as the management staff of the accounting information system. 320 electronic questionnaire forms were distributed via e-mail, while only 237 questionnaires were retrieved. 
$\checkmark$ Time frame of the field study: The study lasted from February 2021 to August 2021.

\subsection{Validity and Reliability of the Study Tool}

$\checkmark$ Validity of the study tool: The tool was verified through the internal consistency of the axes of the study tool by calculating the correlation coefficients between the responses of each axis with the total axes. Table 2 shows the correlation coefficients between the various responses of each axis with the total axes.

Table 2. Correlation of Axis Responses with Total Axes

\begin{tabular}{|c|c|c|c|c|c|c|c|c|}
\hline \multirow{4}{*}{$\begin{array}{c}\text { The first } \\
\text { axis }\end{array}$} & Questions & $\mathbf{1}$ & $\mathbf{2}$ & $\mathbf{3}$ & $\mathbf{4}$ & $\mathbf{5}$ & $\mathbf{6}$ & $\mathbf{7}$ \\
\cline { 2 - 10 } & Pearson correlation & 0.696 & 0.530 & 0.735 & 0.658 & 0.787 & 0.869 & 0.852 \\
\cline { 2 - 9 } & Significance level & 0.000 & 0.000 & 0.000 & 0.000 & 0.000 & 0.000 & 0.000 \\
\hline \multirow{4}{*}{$\begin{array}{c}\text { The } \\
\text { second } \\
\text { axis }\end{array}$} & Questions & $\mathbf{1}$ & $\mathbf{2}$ & $\mathbf{3}$ & $\mathbf{4}$ & $\mathbf{5}$ & $\mathbf{6}$ & $\mathbf{7}$ \\
\cline { 2 - 10 } & Pearson correlation & 0.715 & 0.700 & 0.738 & 0.697 & 0.807 & 0.797 & 0.621 \\
\cline { 2 - 9 } & Significance level & 0.000 & 0.000 & 0.000 & 0.000 & 0.000 & 0.000 & 0.000 \\
\hline \multirow{3}{*}{$\begin{array}{c}\text { The third } \\
\text { axis }\end{array}$} & Questions & $\mathbf{1}$ & $\mathbf{2}$ & $\mathbf{3}$ & $\mathbf{4}$ & $\mathbf{5}$ & $\mathbf{6}$ & $/$ \\
\cline { 2 - 9 } & Pearson correlation & 0.566 & 0.458 & 0.600 & 0.661 & 0.665 & 0.689 & $/$ \\
\cline { 2 - 9 } & Significance level & 0.000 & 0.000 & 0.000 & 0.000 & 0.000 & 0.000 & $/$ \\
\hline
\end{tabular}

Note: Made by the researchers based on $\mathrm{SPSS}_{24}$ program outputs.

The values of the correlation coefficients between the total of each axis and its various responses were mostly between medium and high; they ranged from 0.458 to 0.852 , which exceeded $30 \%$, demonstrating an acceptable degree of correlation. In addition, those correlations of the various expressions were significant because the probabilistic values were less than 0.05 . Therefore, it can be said that there is internal consistency between the statements of the first axis, and all statements can be relied upon in the analysis.

$\checkmark$ Reliability of the study instrument: To evaluate the reliability of the measuring instrument used in this study, which is the questionnaire, the Cronbach's Alpha coefficient was calculated (see Table 3).

Table3. Results of Reliability Test

\begin{tabular}{|c|c|c|c|}
\hline Axis & $\begin{array}{c}\text { Number of } \\
\text { questions }\end{array}$ & $\begin{array}{c}\text { Reliability coefficient } \\
\text { (Cronbach's alpha) }\end{array}$ & $\begin{array}{c}\text { Validity } \\
\text { coefficient }\end{array}$ \\
\hline The first axis & 07 & 0.856 & 0.925 \\
\hline The second axis & 07 & 0.844 & 0.918 \\
\hline The third axis & 06 & 0.694 & 0.833 \\
\hline
\end{tabular}

Note: Made by the researchers based on $\mathrm{SPSS}_{24}$ program outputs.

The reliability coefficients ranged between 0.694 and 0.856 , which exceeded $60 \%$, demonstrating an acceptable degree of correlation. The same correlation was 
achieved for the validity coefficient, which was mostly close to 0.9 , reflecting the validity of the respondents' answers.

\subsection{The Statistical Approach Used}

As the data are ordinal (according to a five-point Likert scale: Strongly Agree, Agree, Neutral, Disagree, Strongly Disagree), nonparametric methods were used. Accordingly, it relies on the frequencies and the median as descriptive statistics. Then a One-Sample Wilcoxon Test was conducted to infer the parameters of the population study.

\section{RESULT AND DISCUSSION}

Presentation and discussion of the results play an important role in the research as the theoretical aspect share applied to the study sample and then the results are generalised to the study population.

\subsection{Personal and Functional Characteristics}

The section presents the personal and functional characteristics of the study sample, which were included due to their relationship to the rest of the study and its various axes (see Table 4).

Table 4. Distribution of the Study Sample

\begin{tabular}{|c|c|c|c|c|c|}
\hline \multicolumn{2}{|c|}{ Occupation } & \multicolumn{3}{c|}{ Experience } \\
\hline Categories & Frequency & Percent & Categories & Frequency & Percent \\
\hline Board member & 37 & 15.60 & Less than 6 years & 64 & 27.00 \\
\hline Department head & 58 & 24.50 & Between 6 and 10 years & 86 & 36.30 \\
\hline Accountant & 78 & 32.90 & Between 11 and15 years & 28 & 11.80 \\
\hline Employer & 64 & 27.00 & More than 15 years & 59 & 24.90 \\
\hline Total & $\mathbf{2 3 7}$ & $\mathbf{1 0 0}$ & Total & $\mathbf{2 3 7}$ & $\mathbf{1 0 0}$ \\
\hline Firm type & & & Firm size & Frequency & Percent \\
\hline Industrial & 32 & 13.50 & Micro & 50 & 21.10 \\
\hline Service & 175 & 73.80 & Small & 77 & 32.50 \\
\hline Mixed & 30 & 12.70 & Midsize & 78 & 32.90 \\
\hline Trequency & Percent & Categories & 32 & 13.50 \\
\hline Total & $\mathbf{2 3 7}$ & $\mathbf{1 0 0}$ & Targe & $\mathbf{2 3 7}$ & Total \\
\hline
\end{tabular}

Note: Made by the researchers based on $\mathrm{SPSS}_{24}$ program outputs. 
From the table above, it is clear that the study sample members varied between heads, board members, accountants, and administrative workers. The institutions at which the respondents work also varied, so that the largest percentage was midsize institutions $(32.9 \%)$. In addition, the years of experience varied per year for the sample under study. The highest percentage was between 6 and 10 years, which amounted to $36.30 \%$. In general, it can be said that the majority of the study sample has a significant period of experience.

\subsection{Results of the Awareness of the Importance of Digital Transformation}

To test the hypothesis related to the awareness of the importance of digital transformation in the Algerian business environment, according to the study sample, Table 5 shows the opinions of the sample members on the awareness of the importance of digital transformation.

Table 5. Results of the First Axis

\begin{tabular}{|c|c|c|c|c|c|c|c|c|}
\hline \multirow{2}{*}{ Question } & \multicolumn{5}{|c|}{ Frequency ratio } & Median & $\begin{array}{c}\text { Sig } \\
\text { Wilcoxon } \\
\text { test }\end{array}$ & Trend \\
\cline { 2 - 9 } & $\begin{array}{c}\text { Strongly } \\
\text { Disagree }\end{array}$ & Disagree & Neutral & Agree & $\begin{array}{c}\text { Strongly } \\
\text { Agree }\end{array}$ & Men \\
\hline 1 & $/$ & $17.7 \%$ & $53.2 \%$ & $29.1 \%$ & $/$ & 3.00 & 0.006 & Agree \\
\hline 2 & $/$ & $20.3 \%$ & $48.9 \%$ & $30.8 \%$ & $/$ & 3.00 & 0.015 & Agree \\
\hline 3 & $13.5 \%$ & $20.3 \%$ & $43 \%$ & $23.2 \%$ & $/$ & 3.00 & 0.987 & Disagree \\
\hline 4 & $19.4 \%$ & $32.9 \%$ & $25.3 \%$ & $22.4 \%$ & $/$ & 2.00 & 0.998 & Disagree \\
\hline 5 & $13.5 \%$ & $10.1 \%$ & $54.9 \%$ & $21.5 \%$ & $/$ & 3.00 & 0.982 & Disagree \\
\hline 6 & $16 \%$ & $16.9 \%$ & $44.7 \%$ & $22.4 \%$ & $/$ & 3.00 & 0.724 & Disagree \\
\hline 7 & $18.6 \%$ & $17.7 \%$ & $48.1 \%$ & $15.6 \%$ & $/$ & 3.00 & 0.983 & Disagree \\
\hline
\end{tabular}

Note: Made by the researchers based on $\mathrm{SPSS}_{24}$ program outputs.

Based on the responses of the sample members to the various questions in this axis, we note the following:

- The frequency of individuals' answers to questions (1 and 2) tends to be "Agree" because the highest percentage is "Neutral" and then - "Agree".

- The frequency of individuals' answers to questions (3-7) tends to "Disagree", because the highest percentage after "Neutral" is "Disagree/ Strongly Disagree".

- Also, the median in most of them is equal to 3, and therefore the Wilcoxon for one sample test must be used, which depends on its median values to judge the direction of the responses, and for the possibility of generalizing the results to the study population.

This test is based on the following assumptions: $\mathrm{H}_{0}$ assumes that the Median $\leq$ 3; and $\mathrm{H}_{1}$ assumes that the Median $>3$.

It is noticed that the Sig Wilcoxon Test values for the two questions (1 and 2) are less than 0.05 , and for the rest of the questions (from 3 to 7 ) they are greater than 0.05 , which confirms the significance of the trend indicated in the last column of the table. 
- It is noticed that the responses of the sample members on this axis, in general, tend towards "Disagree", which means there is a lack of awareness of the importance of digital transformation in business organisations in the Algerian environment.

\subsection{Results of Digital Transformation Practices within Accounting Information Systems}

To test the hypothesis related to the effect of digital transformation on the accounting information systems in the Algerian business environment, according to the study sample, Table 6 shows the opinions of the sample members.

Table 6. Results of the Second Axis

\begin{tabular}{|c|c|c|c|c|c|c|c|c|}
\hline \multirow[b]{2}{*}{ Question } & \multicolumn{5}{|c|}{ Frequency ratio } & \multirow[b]{2}{*}{ Median } & \multirow{2}{*}{$\begin{array}{c}\text { Sig } \\
\text { Wilcoxon } \\
\text { test }\end{array}$} & \multirow[b]{2}{*}{ Trend } \\
\hline & $\begin{array}{l}\text { Strongly } \\
\text { Disagree }\end{array}$ & Disagree & Neutral & Agree & $\begin{array}{c}\text { Strongly } \\
\text { Agree }\end{array}$ & & & \\
\hline 1 & $3.4 \%$ & $16.9 \%$ & $49.8 \%$ & $30 \%$ & I & 3.00 & 0.990 & Disagree \\
\hline 2 & 1 & $21.1 \%$ & $59.9 \%$ & $19 \%$ & 1 & 3.00 & 0.021 & Agree \\
\hline 3 & $11.8 \%$ & $40.5 \%$ & $41.4 \%$ & $6.3 \%$ & 1 & 2.00 & 0.730 & Disagree \\
\hline 4 & $11.8 \%$ & $21.1 \%$ & $44.7 \%$ & $22.4 \%$ & 1 & 3.00 & 0.990 & Disagree \\
\hline 5 & $6.8 \%$ & $27 \%$ & $43 \%$ & $23.2 \%$ & 1 & 3.00 & 0.980 & Disagree \\
\hline 6 & $3.4 \%$ & $24.5 \%$ & $54 \%$ & $18.1 \%$ & 1 & 3.00 & 0.984 & Disagree \\
\hline 7 & $6.8 \%$ & $11.8 \%$ & $58.2 \%$ & $23.2 \%$ & 1 & 3.00 & 0.160 & Disagree \\
\hline
\end{tabular}

Note: Made by the researchers based on $\mathrm{SPSS}_{24}$ program outputs.

Based on the responses of the sample members to the various questions covered in this axis, we note the following:

- The frequency of the individuals' answers to question 2 tends to "Agree".

- The frequency of the individuals' answers to questions (1,3-7) tends to "Disagree" because the highest percentage after "Neutral" is "Disagree/ Strongly Disagree".

- Also, the median in most of them is equal to 3, and therefore the Wilcoxon for one sample test must be used, which depends on its median values to judge the direction of the responses and for the possibility of generalizing the results to the study population.

- It is noticed that the Sig Wilcoxon Test value for question 2 is less than 0.05, and for the rest of the questions (1, from 3 to 7 ), they are greater than 0.05 , which confirms the significance of the trend indicated in the last column of the table.

- It is noticed that the responses of the sample members on this axis, in general, tend towards "Disagree", which means there is a lack of affection for digital transformation on the accounting information systems in business organisations in the Algerian environment. 


\subsection{Results of Digital Transformation Challenges within Accounting Information Systems}

To test the hypothesis related to the extent of the challenges that prevent digital transformation within the accounting information systems according to the study sample, Table7 has been developed.

Table 7. Results of the Third Axis

\begin{tabular}{|c|c|c|c|c|c|c|c|c|}
\hline \multirow[b]{2}{*}{ Questions } & \multicolumn{5}{|c|}{ Frequency ratio } & \multirow[b]{2}{*}{ Median } & \multirow{2}{*}{$\begin{array}{c}\text { Sig } \\
\text { Wilcoxon } \\
\text { test }\end{array}$} & \multirow[b]{2}{*}{ Trend } \\
\hline & $\begin{array}{l}\text { Strongly } \\
\text { Disagree }\end{array}$ & Disagree & Neutral & Agree & $\begin{array}{c}\text { Strongly } \\
\text { Agree }\end{array}$ & & & \\
\hline 1 & l & l & $12.7 \%$ & $44.7 \%$ & $42.6 \%$ & 4.00 & 0.000 & Agree \\
\hline 2 & 1 & 1 & $9.3 \%$ & $58.2 \%$ & $32.5 \%$ & 4.00 & 0.000 & Agree \\
\hline 3 & 1 & 1 & $22 \%$ & $52.7 \%$ & $25.3 \%$ & 4.00 & 0.000 & Agree \\
\hline 4 & $3.4 \%$ & $10.1 \%$ & $9.3 \%$ & $42.6 \%$ & $34.6 \%$ & 4.00 & 0.000 & Agree \\
\hline 5 & 1 & $8.4 \%$ & $25.3 \%$ & $43.5 \%$ & $22.8 \%$ & 4.00 & 0.000 & Agree \\
\hline 6 & l & / & $26.1 \%$ & $57 \%$ & $16.9 \%$ & 4.00 & 0.000 & Agree \\
\hline
\end{tabular}

Note: Made by the researchers based on $\mathrm{SPSS}_{24}$ program outputs.

Based on Table 7 and the responses of the sample members to the various questions covered in this axis, we note the following:

- The frequency of the individuals' answers to questions (from 1 to 7) tends to be "Agree" because the highest percentage after "Neutral" is "Agree/ Strongly Agree".

- Also, the median in most of them is equal to 4 , and therefore the Wilcoxon for one sample test must be used, which depends on its median values to judge the direction of the responses, and for the possibility of generalizing the results to the study population.

- It is noticed that the Sig Wilcoxon Test values for the six questions are less than 0.05 , which confirms the significance of the trend "Agree" indicated in the last column of the table.

- It is noticed that the responses of the sample members on this axis, in general, tend towards "Agree", which means there is a high degree of challenges that prevent digital transformation within the accounting information systems of business organisations in the Algerian environment.

\subsection{Analysis of the Results}

The section discusses the validity of the hypotheses put forward and analyses the results of the study.

- The first sub-question (How important is digital transformation in business organisations?) was answered by rejecting the first hypothesis (Digital transformation is of great importance to decision-makers in business organisations). This is based on the results of Table 5, because most of the 
responses tend towards "Disagree/ Strongly Disagree", while highlighting the statistical significance of that direction.

- The second sub-question was also answered (To what extent does digital transformation affect accounting information systems in business organisations?). The second hypothesis was rejected (business organisations are constantly working to develop their accounting information systems in line with the requirements of digital transformation) through the results of Table 6 . All the responses are within the category "Disagree" or "Strongly Disagree", and the total of this axis is statistically significant.

- The third sub-question was also answered (To what extent do business organisations face challenges related to digital transformation within accounting information systems in business organisations?), by proving the hypothesis (There is a high degree of challenges related to digital transformation within accounting information systems) through the results of Table 7. All of the responses are within the category "Agree" or "Strongly Agree", and the total of this axis is statistically significant.

\section{CONCLUSION}

Accounting information systems have undergone major developments, changes, and updates as a result of the manifestations that are linked to the digital transformation that business organisations have undergone. They are used as outputs by that system rather than functions such as saving, categorising, and summarising.

Most researchers and professionals agree that the need for current accounting personnel will be greatly reduced since the information flow in the system will be immediately supplied with information from smart devices, and therefore, accountants who participate in the digital process will face significant changes in their jobs, duties, and responsibilities during the digital transformation process.

It is necessary for members in charge of accounting information systems to use the developed systems to adapt to this transformation process effectively so that the transformation can be achieved by combining the different elements to create the system and ensure its effective continuity.

Based on what was presented in the conceptual aspect and its use in the practical aspect to diagnose reality and inventory opportunities and challenges in the Algerian environment, the results can be presented as follows:

- The first hypothesis has been rejected, and therefore it can be said that business organisations in the Algerian environment seek to develop their accounting information systems to a weak degree in line with the requirements of digital transformation;

- The second hypothesis has been rejected, and therefore it can be said that business organisations in the Algerian environment seek to develop their accounting information systems to a low degree in line with the requirements of digital transformation;

- The third hypothesis stating that there is a high level of challenges associated 
with digital transformation within accounting information systems has been accepted.

In light of the results obtained, the following recommendations can be made:

- Business organisations in the Algerian environment should train their employees to deal with digital transformation techniques through practical cases;

- There is a need to diversify the skills of those in charge of accounting information systems to deal with the challenges posed by the modern environment of business organisations in light of digital transformation, and to qualify for many of the newly developed future roles;

- There is necessity for Algerian universities to hold seminars, conferences, invite accountants and managers, and explain the benefits and challenges expected from adopting digital transformation techniques in the fields of management and accounting.

\section{REFERENCES}

Akter, S., Michael, K., Uddin, M. R., McCarthy, G., \& Rahman, M. (2020). Transforming business using digital innovations: The application of AI, blockchain, cloud and data analytics. Annals of Operations Research, 1-33. https://doi.org/10.1007/s10479-020-03620-w

Al-Zoubi, A. M. (2017). The effect of cloud computing on elements of accounting information system. Global Journal of Management and Business Research, 17(3), 1-8.

Andreassen, R. I. (2020). Digital technology and changing roles: a management accountant's dream or nightmare? Journal of Management Control, 31(3), 209-238. https://doi.org/10.1007/s00187-020-00303-2

Baethge-Kinsky, V. (2020). Digitized industrial work: requirements, opportunities, and problems of competence development. Frontiers in Sociology, 5(33), 1-13. https://doi.org/10.3389/fsoc. 2020.00033

Begum, D. (2019). Digital Transformation of Accounting in India, Emperor International Journal of Finance and Management Research, 5(10), 6-12.

Bygren, K. (2016). The digitalization impact on accounting firms business models [Master of Science in Industrial Engineering and Management, Stockholm University]. Thesis Stockholm. https://n9.cl/0xp6t

Correani, A., De Massis, A., Frattini, F., Petruzzelli, A. M., \& Natalicchio, A. (2020). Implementing a digital strategy: Learning from the experience of three digital transformation projects. California Management Review, 62(4), 1-20. https://doi.org/10.1177/0008125620934864

Demiröz, S., \& Heupel, T. (2017, November 30 -December 1). Digital Transformation and its radical changes for external management accounting: a consideration of small and medium-sized enterprises. FDIBA Conference Proceedings. https://n9.cl/gt82x

Faccia, A., \& Mosteanu, N. R. (2019). Accounting and blockchain technology: from double-entry to triple-entry. The Business \& Management Review, 10(2), 108-116.

Gupta, S. (2018). Organizational barriers to digital transformation, [Master of Science in Industrial Engineering and Management, Stockholm University]. Thesis Stockholm. https://n9.cl/gltzr

Hess, T., Benlian, A., Matt, C., \& Wiesböck, F. (2016). How German media companies defined their digital transformation strategies. MIS Quarterly Executive, 15(2), 103-119.

Lazarova, V. (2019). Digitalization and Digital Transformation in Accounting. Ikonomices kii Sotsialni Alternativi, (2), 97-106.

Mitrofanova, E. A., Konovalova, V. G., \& Mitrofanova, A. E. (2018). Opportunities, problems and limitations of digital transformation of HR management. In The European Proceedings of Social \& Behavioural Sciences Ep SBS, 1717-1727. https://dx.doi.org/10.15405/epsbs.2019.03.174 
Nguyen, M. T., Nguyen, Q. H., \& Nguyen, T. H. (2021). Digital transformation in the business: a solution for developing cash accounting information systems and digitizing documents. Science and Technology Development Journal, 24(2), 1975-1987. https://doi.org/10.32508/stdj.v24i2.2526

Oncioiu, I., Bîlcan, F. R., Stoica, D. A., \& Stanciu, A. (2019). Digital Transformation of Managerial Accounting-Trends in the New Economic Environment. EIRP Proceedings, 14(1), 266-274.

Othman, O. H. O., \& AL-Dweikat, M. F. S. (2021). The Impact of Digital Transformation Risk Management on the Credibility of Accounting Information in Jordanian Commercial Banks. Psychology and Education Journal, 58(2), 3893-3904.

Parlak, N. (2020). Change of the accounting profession in the age of digital transformation. In Academic Studies in Social Sciences.

Phornlaphatrachakorn, K., \& NaKalasindhu, K. (2021). Digital Accounting, Financial Reporting Quality and Digital Transformation: Evidence from Thai Listed Firms. The Journal of Asian Finance, Economics and Business, 8(8), 409-419.

Rehm, S. V. (2017). Accounting Information Systems and how to prepare for Digital Transformation. In The Routledge Companion to Accounting Information Systems, 69-80. https://doi.org/10.4324/9781315647210-6

Saarikko, T., Westergren, U. H., \& Blomquist, T. (2020). Digital transformation: Five recommendations for the digitally conscious firm. Business Horizons, 63(6), 825-839. https://doi.org/10.1016/j.bushor.2020.07.005

Saed, K. A. M. (2020). Assessment of the impact made by the digital transformation of the accounting system on the decision-making system of the enterprise. Evropský Ćasopis Ekonomiky A Managementu, 5(6), 122-129. https://doi.org/10.46340/eujem.2020.6.2.15

Tekbas, I., \& Nonwoven, K. (2018). The Profession of the digital age: Accounting Engineering. IFAC Proceedings Volumes, Project: The Theory of Accounting, Enginnering.

Thipwiwatpotjana, S. (2021). Digital Transformation of Accounting Firms: The Perspective of Employees from Quality Accounting Firms in Thailand. Human Behavior, Development and Society, Conference proceedings, 22(1), 53-62.

Timchev, M. (2020). Accounting Business Analysis of The Company in The Conditions of Competition and Digital Transformation. Economic Science, education and the real economy: Development and interactions in the digital age, (1), 151-161.

Vial, G. (2019). Understanding digital transformation: A review and a research agenda. Journal of strategic information, 28(2). https://doi.org/10.1016/j.jsis.2019.01.003

Yao, Q., \& Gao, Y. (2020, October). Analysis of Environment Accounting in the Context of Big Data. In Journal of Physics: Conference Series (Vol. 1650, No. 3, p. 032081). IOP Publishing. https://doi.org/10.1088/1742-6596/1650/3/032081

\section{AUTHORS' SHORT BIOGRAPHIES}

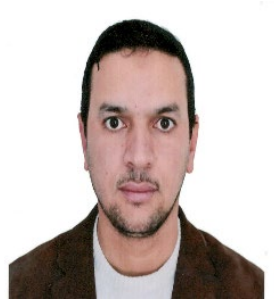

Oualid Meraghni received his Master degree in 2011 and his $\mathrm{PhD}$ degree in 2017 in accounting and information systems from the University of Mohammed Khider, Biskra, Algeria. The author has been a Lecturer at the University of Echahid Hamma Lakhdar, El-Oued, since 2017. His main research fields are management, accounting and finance.

E-mail: meraghni-oualid@univ-eloued.dz

ORCID iD: https://orcid.org/0000-0001-9713-2461 


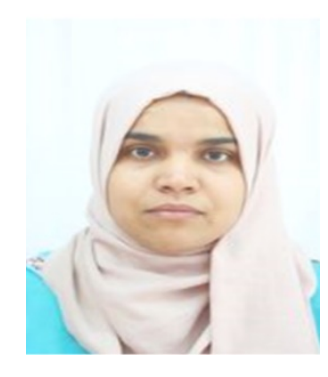

Latifa Bekkouche received the Master degree in accounting and information systems from the University Centre of El-Oued, Algeria in 2011 and the $\mathrm{PhD}$ degree in management in 2017 from Mohamed Khider University of Biskra, Algeria. The author has been a Lecturer at the El-Oued University in Algeria since 2017. The main research interest is management accounting studies.

E-mail: latifa-bekkouche@univ-eloued.dz

ORCID iD: https://orcid.org/0000-0002-5995-981X

Zakaria Demdoum obtained a Master degree in economic sciences, specialising in economic analysis, from the University of Algiers 3 in 2002 and a Doctorate of Science degree, specialising in economic analysis, from the University of Algiers 3 in 2015 and a university qualification certificate in 2017. He was promoted to professor of higher education in 2021. He has been a lecturer at El-Oued University since 2003. The main research interest is studies in corporate finance, financial and management accounting.

E-mail: demdoum-zakaria@univ-eloued.dz

ORCID iD: https://orcid.org/0000-0002-7082-9098 